\title{
International Economics
}

\author{
Oleksandr SHAROV
}

\section{GLOBALIZATION: LATEST TRENDS OR PERMANENT DEVELOPMENT DIRECTION?}

\begin{abstract}
The article views economic globalization in the theoretical and historical context. Analysing the origins of terminological interpretations, a new approach is being developed regarding the globalization's objectivity and irreversibility as an inherent element in the development of the human community and international economic relations. Its commonalities and differences from the internationalization of the world economy are indicated. This raises the question of the globalization's timing as a process, to answer which there are different approaches. The author examines the existing variants of periodization of globalization processes, as well as its peculiarities in the times of the global financial crisis of 2008-2010. He concludes that globalization is an objective process of the human community (economic) development of the area of its residence and that it is characteristic for the whole period of humanity's existence. It is caused by the innate propensity of humanity for cooperation. However, it revealed its clear orientation after the Age of Discovery, intensified in the late nineteenth century (due to the industrialization of leading European nations and the colonization of the African continent and other non-European territories) and became a major trend in world economic development in the late $20^{\text {th }}-$ early $21^{\text {st }}$ centuries. Particular attention is paid to

(C) Oleksandr Sharov, 2020.

Sharov Oleksandr, Doctor of Economic Sciences, Professor, Chief of the Foreign Economic Policy Department, National Institute for Strategic Studies, Ukraine. ORCID: http://orcid.org/0000-00018460-9996, Email: osharov@niss.gov.ua.
\end{abstract}


the problem of using a single national currency as an international means of payment (referring primarily to the US dollar), which is a feature of the current stage of globalization.

\section{Key words:}

Globalisation, internationalisation, international economic relations, world economic order.

JEL: F60.

\section{Problem Statement}

Globalization is a major factor in the development of the modern economy - both at the level of national economies of individual countries and at the global level. At the same time, the process of globalization is ambiguous: it is characterised by certain fluctuations and changes in conceptual principles, which causes some researchers to feel uncertain about its future nature and results. Thus, it is necessary to ascertain the role of globalization in the historical process of human development in order to determine the directions of its main long-term tendencies.

The term "globalization» appeared in the vocabulary of researchers back in the 1930s outside economic science and, according to some experts, received its economic meaning in the 1940s. In 1961, the term was added to the Webster's dictionary, and it gradually began to overtake its French counterpart «mondialisation», which, in principle, can be considered the original one.

The next step in spreading this term was the use of the rather successful expression «global village», which belongs to Canadian philosopher M. McLuhan (War and Peace in the Global Village, 1968). In 1983, Harvard Business School professor T. Levitt introduced the broad and, so to speak, "documented» use of the term "globalization» into the economic lexicon in an article «Market Globalization", published in the May issue of Harvard Business Review and shortly reprinted in another well-known publication - McKensey Quarterly (T. Levitt, 1984). However, at that time, the very concept of «globalization» was used in a rather 
ISSN 2519-4070

narrow sense - the policy of large («global») corporations of adapting markets "to themselves» (as opposed to the actions of "multinational corporations", which adapt to many national markets). With regard to the processes of unification, the article stated that the world is becoming «homogenized», i.e. has a stable homogeneous structure.

Further understanding of the term «globalization» was developed in depth by many researchers. In particular, M. Albrow and E. King (1990) have drawn attention to such characteristic qualities as the inclusion («incorporation») of people into a single world society. R. Robertson (1992) of the University of Aberdeen (Scotland) defined globalization as «compression of the world and the intensification of the global consciousness as a whole». The essence of this side of globalization was clarified by A. Giddens (1991), defining it as the intensification of world social relations, which connects remote places in such a way that local events are influenced by phenomena that occurred at a long distance and vice versa. Thus, understanding of the concept of «globalization» went beyond being a purely economic phenomenon. «...it should not be forgotten that, although usually it is economic globalisation that many people have in mind when they talk about globalisation, economic globalisation is only one aspect (or one component) - though the main one - of globalisation» (T. Fotopoulos, 2001). Noting this, the contemporary Greek philosopher and economist, leader of the «democracy of participation" movement, T. Fotopoulos, notes that while other aspects of globalization (political, cultural, technological, etc.) are very interconnected, it can nevertheless be argued that economic globalization defines the conditions for the development of other aspects of the entire globalization process. The explanation for this fact is that in a market economy, the economic element is dominant in a society (although this does not exclude some autonomy of other elements).

Theoretical and applied aspects of globalization, understanding of the nature and prospects of its development, influence on national economies and the global economic system were covered in the works of many Ukrainian and foreign scientists, including V. Bazylevych, Z. Bzhezinskyi, O. Bilenkyi, O. Bilorus, A. Halchynskyi, V.Heiets, S. Korablin, D. Lukianenko, Yu. Makohon, Yu. Pakhomov, V. Sidenko, A. Filipenko and others. However, in our opinion, the issues of origin, periodization and long-term trends of globalization require further investigation.

\section{Main Findings}

The relationship between different elements of social relations is asymmetric in the sense that the economic component determines the conditions for political relations in a society with a market economy. However, the economic component of globalization is defined in different ways. Some focus on the creation of 
a single economic mechanism under the influence of transnational corporations, others consider the creation of global financial and information space to be the main feature of globalization, and others still see it as a destructive power created by the so-called "golden billion» under the guise of liberal values.

Professor of St. Petersburg State University V. M. Shavshukov (2012) believes that «Globalization in economic terms reflects the growing integration of economies around the world, which manifests by increasing not only trade and financial flows, but also the cross-border movement of labour and technology". Well-known American scientist M. Bordo (2001) defines «globalization as the increasingly close international integration of markets for goods, services and factors of production, labour and capital». Meanwhile, in the opinion of T. Fotopoulos, this is not quite true, since it is necessary to draw a clear line between economic globalization and the internationalization of a market economy. "Internationalization» means that national markets and borders exist, but the flow of capital, goods and (to some extent) labour is unrestricted; sovereign nation states exist, but they share power with transnational corporations (TNCs) in a system where the role of the state is gradually being reduced to providing a stable basis for a cost-effective market. On the other hand, «globalization» refers to a «world economy without borders" in which economic nationalism has already been eliminated and production itself has become international in the sense that large corporations have become stateless institutions involved in the integrated internal division of labour, which encompasses many countries.

To reflect this new reality, a well-known American journalist $T$. Friedman even coined the term «flat world» in his book The World Is Flat. This is derived from the expression «level playing field», which generally refers to a «homogeneous competitive environment», "an environment with the same rules» and finally, «equal opportunities. In his opinion, the whole world has become one-level and «flat». As a kind of flatteners, he called: 1) the fall of the Berlin Wall in 1989 («when the wall fell, the windows opened»); 2) the launch of Netscape, whose browser first gave customers broad access to the World Wide Web - in 1995; 3) workflow software for remote work - such as SMTP and HTLM. These three events have become the genesis of globalization, a kind of platform on which globalization has evolved thanks to other «flatteners». These are 4) uploading systems that allowed free and fast access to information from various Internet sources; 5) outsourcing, which allowed companies to spread their staff around the world; 6) offshoring* which made it possible to minimize production costs by moving production facilities and individual units of companies abroad; 7) «supply chains» of modern corporations, especially in the retail industry; 8) insourcing - a system whereby one company can perform work on behalf of another (for example, warranty repairs for a well-known brands); 9) rapid development of digitalisa-

\footnotetext{
*In this case, we mean the opening of branches or separate divisions of companies not only directly in the «offshore zones», but also abroad in general.
} 
tion and 10) what the author called «steroids" - wireless technology (mobile phones, iPods, digital cameras, etc.) that allow instant messaging or transmission of audio and video information. All this, according to T. Friedman, has been changing the world - for better or worse.

Of course, opponents were quick to explain why the world is not flat (Pankaj Ghemawat), moreover, assure that "the world is round» (John Gray) or even «pointed» (Richard Florida). Joseph Stiglitz (2006), a well-known economist, has explicitly stated that «not only is the world not flat, but it is in many ways getting less flat».

In concluding this brief review, I would like to draw your attention to two other theories that are of particular importance in terms of monetary theory. According to the classification proposed by the famous Turkish-American scientist D. Rodrik, there are three stages of capitalism. Capitalism 1.0 is an ideal market society, described by A. Smith, and covers times when the government assumed only very limited economic commitments. A radical change occurred after the Great Depression of 1929-33, when "capitalism 2.0" emerged with the Keynesian model of «mixed economy». Capitalism 2.0 came along with limited globalization, which was reflected in the Bretton Woods compromise. However, in the 1970 s and 1980s, this model also began to fail. Thus, according to the author, "We must create a new model of capitalism for the new century, in which there will be much more powerful forces of economic globalization» (D. Rodrik, 2014). At the same time, an equally well-known British economist (member of the Council of the Royal Economic Society), USSR-born A. Kaletsky (2011) proposed another, more detailed classification, according to which capitalism underwent several qualitative stages in the course of its development:

Capitalism 1: From Adam Smith and Alexander Hamilton to Lenin, Hoover and Hitler

Capitalism 1.0: from the 1776 Declaration of Independence and the Wealth of Nations to the 1815 Waterloo defeat of Napoleon

Capitalism 1.1: from 1820 to 1849 (probably from the beginning of the reign of British King George IV to the European uprisings of the Spring of Nations - O. Sharov)

Capitalism 1.2: from 1848-49, the years of the European revolutions, the abolition of the Corn Law and the Naval Acts (which promoted free trade O. Sharov) till the end of 1860 , including the eradication of the effects of the Civil War in the United States and the Franco-Prussian war

Capitalism 1.3: from 1870 to 1914, including the Gilded Age (1870-1900, when according to $M$. Twain who coined the term, social problems were hidden under a thin layer of gold "economic growth" - O.Sharov) in the United States and the Second Industrial Revolution 
Capitalism 1.4: from 1917 to 1932, a period of disintegration, when capitalism came closer than ever to complete collapse before or after.

Capitalism 2: from Roosevelt and Keynes to Nixon and Carter

Capitalism 2.0: 1931-1938, abandoning the gold standard and experimenting with the New Deal

Capitalism 2.1: 1939-1945, state militarism

Capitalism 2.2: 1946-1969, the "golden age» of Keynesianism

Capitalism 2.3: 1970-1980, inflation, the energy crisis, and the collapse of the post-war monetary system (pegged to gold).

Capitalism 3: from Thatcher, Reagan and Milton Friedman to Bush, Paulson and Greenspan

Capitalism 3.0: 1979-1983, early monetarism and trade union confrontation

Capitalism 3.1: 1984-1992, Volcker and Greenspan, the Thatcher-Reagan boom

Capitalism 3.2: 1992-2000, Great Moderation (the term used in opposition to Great Depression to indicate that this time the state managed to cope with the market crisis - O.Sharov)

Capitalism 3.3: 2001-2008, market fundamentalism following the principles of Greenspan and G. Bush.

Then came the global financial crisis of 2008-10, which led to Capitalism 4.0. This transformation was prepared by the fundamental changes that took place over the past twenty years (since 1989, which A. Kaletsky calls «the year of miracles" - Annus Mirabilis of 1989). The five dramatic changes that have taken place since that time are: 1) completion of the 70-year communist experiment, 2) rapid growth of Asia (and especially China) as part of the global economy, 3) technological and information revolution that accelerated at the end of 1980 's, 4) «peaceful dividends» that arose from the end of the Cold War, and 5 ) the demystification of money. This latest change, least perceptible to the general public, is perhaps the most interesting to us. The author refers to the actual collapse of the Bretton Woods system, the completion of the demonetisation of gold (together with the closing of the "golden window" by President R. Nixon in 1971 , the full transition to a system of credit money, and the possibility of creating "collective» or regional monetary units ( first of all, the euro). That is to say, a series of changes that have enabled governments to manage (well or not) their national economies. According to A. Kaletsky (2011), «this revolutionary demystification of money did for economic policy what the French Revolution did for the state religion». 
Thus, summarizing the above, we can say that globalization is a process of comprehensive universalisation of the humanity's living conditions on a global scale in combination with unprecedented simplification of local and transcontinental communication. It is a process that covers almost all - everyday, cultural, religious, environmental, information, economic, political - aspects of human life.

This raises the question of the timing of the globalization process, to which there are three main approaches (B. Gills, 2006).

Some experts believe that global history is actually part of the same process that we can call globalization that is, globalization began simultaneously with the process of anthropological and socio genesis. In particular, D. Wilkinson (2003) believes that the beginning of globalization reaches the historical and biological roots of humankind. Another well-known researcher, R. Wescott (2000) links the beginning of globalization with the Neolithic revolution (8 thousand years ago). A. Frank (1993) dates the history of globalization back to at least five thousand years ago, since, in his opinion, the global system began to form in the Bronze Age (between 4000 and 1200 B. C.) in southwest Asia (Middle East), extending further to Asia, Europe and North Africa.

Other experts do not agree with this interpretation, quite rightly noting that if this is the case, the concept of global history (history of humanity) and globalization simply coincide and then the need for the concept of globalization is not clear. Proponents of this approach mark the beginning of globalization in later periods of human history, usually between the beginning of the sixteenth and the end of the nineteenth centuries.

Finally, there are those in the middle who do not recognize the need for a strict analytical and historical division between global history and globalization, since the latter is understood as a broad set of processes (not necessarily without precedents) that are rather specific and thus require some clear distinction from the whole continuum of "global history».

Globalization is a natural, objective process of growing global (comprehensive) problems and attempts of the international community to solve them jointly, caused by the inherent predisposition of humanity towards cooperation. In this respect, there are two major ways in which the current situation is different from that which existed during the two last centuries. Firstly, no country can cope with global challenges on its own because the problems have become too complex and too many players compete on the international stage. Secondly, most nations face similar challenges - from fighting pandemic diseases to combating international terrorism - and are becoming aware of the need to transform common interests into common actions. As a result, states have discovered clear strong incentives to work together collectively and to assume partial responsibility. (H. Clinton, 2009). 
Meanwhile, although national governments are no less important, they have to change their roles. In particular, there is a gradual transition to a new world order (R. Haas (2017) «World Order 2.0»), which provides for the Westphalian principle of «responsible sovereignty» being replaced by the principle of "sovereign responsibility" or even "sovereign obligations", in accordance with which sovereign states should have not only rights but also obligations to other countries. Sovereign obligations entail a variety of measures in the economic field. This is because given their own interests, governments have incentives to address issues such as ensuring the viability of the national currency, having sufficient liquid reserves in commercial banks, eradicating corruption, developing international trade, and attracting foreign investment. However, there are other problems. In particular, trade agreements are by definition contracts concerning mutual sovereign obligations in the field of tariff and non-tariff barriers. If one of the parties considers that these obligations are not fulfilled, it may proceed to arbitration within the World Trade Organization. Nevertheless, the situation becomes less transparent when it comes to government subsidies or exchange rate manipulation. The aim, therefore, is to formulate appropriate sovereign commitments in these areas in future trade agreements and to create mechanisms for government accountability.

The problem of using a single national currency as an international means of payment is particularly noteworthy (first of all, in terms of the US dollar). In this case, the issue of the international responsibility for the monetary policy by the country of origin of such currency becomes increasingly acute, which is quite logical as it affects the economic situation of other countries in the world. Of course, within the paradigm of responsible sovereignty, it can be argued that countries that allow dollarization (to varying degrees) should themselves be responsible for their sovereign decision. However, the «single chain» countries of globalization can no longer build international relations on this basis.

Internationalization of the economy is an important process underlying globalization (and sometimes even equated with globalization). However, this process concerns the emergence of a global economy consisting of national economies that interact. Meanwhile, globalization, in essence, leads to diminishing national economic boundaries and to the transformation of the world economy into one whole. Thus, the process of internationalization has begun much earlier, marking the expansion of export of commodities outside the national economy and at the same time the influx of foreign goods from abroad, the provision of services to foreigners and access to foreign services, foreign investment in the national economy and national investment abroad, labour emigration and immigration. In other words, internationalization means the convergence of national economies through increased industrial cooperation and the interdependence of international trade, capital flows and labour between the countries. There are three main stages in the development of internationalization of economic activity. 
The first stage (the end of the eighteenth - the end of the nineteenth century) - the internationalization of production is based mainly on the interaction of national economies through simple cooperation. The main channels of mutual «metabolism» were the simplest forms of international economic relations and, above all, foreign trade. Internationalization of production and circulation has become one of the main prerequisites for the formation of the world economy.

The second stage (end of XIX - middle of XX century) internationalization of production goes to another stage, which is connected with the development of complex cooperation. A characteristic feature of complex cooperation is its foundation in the international division of labour, which becomes a determining factor in deepening the internationalization of economic life and the formation of the world economy.

The third stage (beginning in the middle of the twentieth century) is characterized by the complexity of the internationalization of production (covering all subsystems of the economy, extending to almost all countries of the world, all branches of the production and non-productive spheres). It is through internationalization that the main conditions for balanced economic development are fulfilled: the gross national product (GNP) is transformed into its physical and monetary expression, the quality of human development is improved, etc.

However, without internationalization, there is no globalization, the latter follows the former. Globalization is a qualitatively new and higher stage of internationalization, encompassing a much wider sphere of life. The process of globalization has grown gradually, developing its elements - internationalization, economic liberalization, urbanization, transnational corporatization, desovereignty, etc. - in order to finally present itself in its full form, which we can observe from the beginning of the twentieth century. Of course, this globalization process has had a long historical path that can be divided into three major stages: pre-modern, modern and post-modern.

The key concept of such periodization is, of course, the «modern». There are at least two interpretations in historiography that consider it. The first is based on the juxtaposition of «modernity» and «tradition», that is, modern society and ancient. In this case, «modern» refers to the whole Modern Age, which "officially» began with the Turks taking Byzantium in 1492. More detailed periodization of modern times claims that the Modern Age started at the end of the $19^{\text {th }}$ century and lasted until the middle of the $20^{\text {th }}$ century, after which the Contemporary history began its dating. 


\section{Conclusions}

Thus, we conclude that globalization is an objective process of the human community's (economic) development of the area of its residence and that it is characteristic for the whole period of humanity's existence. It is caused by the innate propensity of humanity for cooperation. However, it revealed its clear orientation after the Age of Discovery, intensified in the late nineteenth century (due to the industrialization of leading European nations and the colonization of the nonEuropean territories) and became a major trend in world economic development in the late $20^{\text {th }}-$ early $21^{\text {st }}$ centuries.

\section{References}

1. Albrow M., King E. (1990). Globalization, Knowledge and Society. London: SAGE, $288 \mathrm{p}$.

2. Bordo M. (2002). Globalization in Historical Perspective. Business Economics, pp. 20-29.

3. Clinton H. (2009). Foreign Policy Address at the Council on Foreign Relations, Retrieved from: http://www.state.gov/secretary/rm/2009a/july/126071.htm

4. Fotopoulos T. (2001). Globalization, the reformist Left and the AntiGlobalization «Movement». Democracy \& Nature: The International Journal of Inclusive Democracy, 7(2), Retrieved from: http://www.staff.ncl.ac.uk/ david.harvey/AEF806/Fotopoulos.pdf

5. Frank A.G. (1993). The Bronze Age World System and its Cycles. Current Anthropology, 34, pp. 383-413.

6. Giddens A. (1991). The Consequences of Modernity. Cambridge: Polity Press, 200 p.

7. Gills B.K., Thompson W.R. (2006). Globalizations, History and Historical Globalities. Globalization and Global History. L, N.Y.: Routledge, 320 p.

8. Haas R. (2017). World Order 2.0. Foreign Affairs, pp. 2-9.

9. Kaletsky A. (2011). Capitalism 4.0. The Birth of New Economy. L.: Bloosbury, $448 \mathrm{p}$.

10. Levitt T. (1984). Globalization of Markets. McKensey Quarterly, Retrieved from: http://www.lapres.net/levit.pdf

11. Robertson R. (1992). Globalization: social theory and global culture. London: SAGE, $224 \mathrm{p}$. 
12. Rodrik D. (2014). The Globalisation Paradox. Moscow: Gaidar Institute for Economic Policy, 576 p. (in Russian)

13. Shavshukov V.M. (2012). "Changing of the guard» in the Global Economy: Scenario Assessment. USA v Canada: Economics - Politics - Culture, 12, pp. 23-38. (in Russian)

14. Stiglitz J. (2006). Making Globalization Work. N.Y., 374 p.

15. Wescott R.W. (2000). Comparing Civilizations. An Unconsensual View of Culture History. Atherton: Atherton Press, $377 \mathrm{p}$.

16. Wilkinson D. (2003). Globalizations: The First Ten, Hundred, Five Thousand, and Million Years. Comparative Civilization Review, 49(49), pp. 132-145. 